\title{
Uropygial gland size and composition varies according to experimentally modified microbiome in Great tits
}

Staffan Jacob ${ }^{1,2^{*}}$, Anika Immer ${ }^{1}$, Sarah Leclaire ${ }^{3}$, Nathalie Parthuisot ${ }^{1}$, Christine Ducamp $^{1}$, Gilles Espinasse ${ }^{1}$ and Philipp Heeb ${ }^{1}$

\begin{abstract}
Background: Parasites exert important selective pressures on host life history traits. In birds, feathers are inhabited by numerous microorganisms, some of them being able to degrade feathers or lead to infections. Preening feathers with secretions of the uropygial gland has been found to act as an antimicrobial defence mechanism, expected to regulate feather microbial communities and thus limit feather abrasion and infections. Here, we used an experimental approach to test whether Great tits (Parus major) modify their investment in the uropygial gland in response to differences in environmental microorganisms.

Results: We found that males, but not females, modified the size of their gland when exposed to higher bacterial densities on feathers. We also identified 16 wax esters in the uropygial gland secretions. The relative abundance of some of these esters changed in males and females, while the relative abundance of others changed only in females when exposed to greater bacterial loads on feathers.

Conclusion: Birds live in a bacterial world composed of commensal and pathogenic microorganisms. This study provides the first experimental evidence for modifications of investment in the defensive trait that is the uropygial gland in response to environmental microorganisms in a wild bird.
\end{abstract}

Keywords: Preen gland, Microorganisms, Host-microbiome interactions, Wax esters, Parus major

\section{Background}

Microorganisms such as bacteria and fungi are widespread and constitute the major part of the earth biomass [1,2]. While parasites exert strong selective pressure on host lifehistory traits [3], beneficial microorganisms can be involved in various processes such as digestion, nutrient synthesis or protection from pathogen colonisation [4-7]. Recently, several studies highlighted the potential role played by the whole assemblage of microorganisms (usually referred as "microbiome" [8]), as selective pressures shaping the evolution of host life history traits [7-12].

\footnotetext{
*Correspondence: jacobstaffan@gmail.com

'Laboratoire Évolution et Diversité Biologique (EDB), UMR 5174 Centre National de la Recherche Scientifique (CNRS), Ecole Nationale de Formation Agronomique (ENFA) - Université Paul Sabatier, 118 Route de Narbonne, 31062 Toulouse, France

${ }^{2}$ Now at Station d'Ecologie Expérimentale du CNRS à Moulis, USR2936, 09200 Saint-Girons, France

Full list of author information is available at the end of the article
}

Birds carry a large variety of potential pathogens on their plumage [13]. Some can potentially lead to infections [13], while keratinolytic microorganisms have the ability to degrade feathers as found under laboratory conditions [14-16] and might thus alter plumage integrity $[16,17]$. Alternatively, some microorganisms might be beneficial, for instance by maintaining microbial community stability through competition and cooperation, thus preventing colonisation by environmental pathogens $[7,8,18,19]$. Given the importance of avoiding pathogen infections and maintaining good plumage integrity, birds are expected to have evolved means to regulate the microorganisms on their feathers [17]. The uropygial gland is an external gland present in almost all bird species, which produces secretions that are coated on feathers during preening. Preen secretions can contain antibacterial substances [20-24]. In the House finch (Carpodacus mexicanus), uropygial gland secretions have been found to inhibit the in vitro growth 
of both keratinolytic and non-keratinolytic isolated bacterial strains [20]. Preening feathers with uropygial gland secretions might consequently act as an antimicrobial defence mechanism to regulate microorganisms on feathers $[20,21,25,26]$.

Hosts and their microbiome are involved in reciprocal interactions where a host response can affect its microbial communities [1,2]. Microbial communities present on birds are highly diverse and can show rapid changes in density and composition [27-29]. Consequently, we might expect birds to modify investment in their uropygial gland in relation with the microbial pressures they face [30]. Since uropygial gland secretions and preening behaviour have been suggested to be costly in terms of time, energy and probability of olfactory detection by predators [31,32], we indeed expected birds to adjust gland investment to the levels required for optimal protection against microorganisms [30]. Uropygial gland size and composition of secretions have been found to show seasonal variations and to depend on hormonal levels [32-34]. The uropygial gland is thus a plastic trait that might consequently vary depending on the need for microbial protection. Several studies have examined the effects of uropygial gland secretions on microorganisms $[20,25,26,35]$ and the correlations between gland size and microbial communities on feathers [21]. However, to date no study has examined experimentally whether birds respond to their exposure to environmental microorganisms by modifying their investment in uropygial gland size and/or composition of secretions.

In this study, we experimentally modified Great tit exposure to environmental microorganisms during reproduction to investigate whether birds modify their investment into their uropygial gland in relation to their microbiome. We randomly allocated nests to three treatment groups: two groups of nests were sprayed with liquid solutions that either favoured or inhibited bacterial growth, and a third group acted as control. Since birds are in contact with their nests during breeding, we expected these treatments to affect bacterial communities on bird feathers. We know little about the influences of environmental microorganisms on feather microbial assemblages. Consequently, investigating how modifications of nest microbiome affect the density and composition of feather microbial communities will help to understand the link between environmental bacterial communities and those carried by birds on their feathers.

We measured the volume of the Great tit uropygial gland and analysed the chemical composition of the gland secretions at the end of the reproductive event. We predicted that birds should adjust uropygial gland investment in function of their exposure to microorganisms. Great tits males and females differ in exposure to nest microorganisms, reproductive strategies, immunity and uropygial gland size [29,36-39]. We thus expected that modified bacterial exposure should lead to sex-specific differences in changes of gland volume and composition. Given our limited knowledge of the ecological interactions between microbial communities and hosts, we could not make a priori predictions on the direction of the expected effects of treatments on gland investment and whether Great tits adjust the size and/or composition of their secretions. However, effects of modifications of Great tit microbiome would provide the first experimental evidence for a role of the microbial environment in bird investment in the defensive trait that is the uropygial gland.

\section{Methods}

\section{Experimental design}

The study was performed during the reproductive seasons 2011 and 2012 on a Great tit population breeding in nest boxes close to Toulouse, France ( $\left.43^{\circ} 39^{\prime} \mathrm{N}, 1^{\circ} 54^{\prime} \mathrm{E}\right)$. In the winter, old nest material was removed from the nest boxes and boxes were scraped with a hard brush. Nest boxes were visited daily from the beginning of March to detect the beginning of nest building.

In order to modify bird microbiome, we randomly assigned the nests to three treatments. Firstly to favour the bacterial growth in the nests we used TSB (Tryptic Soy Broth, $40 \mathrm{mg} / \mathrm{L}$ in sterilized distilled water, Sigma), a liquid general growth media for heterotrophic microorganisms commonly used in microbiology. Nisin in association with EDTA, a bacteriostatic solution used for food conservation (7 g Nisin (900 IU/mg; B\&K Technology Group) in $50 \mathrm{mM}$ EDTA $[40,41])$ was used to inhibit bacterial growth in the nests. TSB and Nisin were diluted in water, and humidity can favour microbial growth $[42,43]$. Consequently, we used water as a control in order to have similar humidity levels in the three treatments. Differences between treatments in Great tit uropygial gland would thus result from effects of TSB and Nisin solutions on bacterial communities and not from potential humidity effects. After carefully removing the eggs or the nestlings, the three solutions (TSB, Nisin and water) were sprayed (mean volume $1.7 \pm 0.02 \mathrm{ml}$ ) in the centre of the nest cup every two days during the whole reproductive period (from the beginning of nest building to nestling fledging; total number of treatments per nest; mean \pm SE: $16.6 \pm$ 0.3 ; no significant difference between treatments: $\mathrm{X}^{2}=$ 4.02; $\mathrm{df}=52 ; \mathrm{p}=0.13)$. During incubation, nests were treated only on day 1, 5 and 9 after the start of incubation in order to limit the risks of nest desertion. A total of 54 nests were included in our study (17 nests in the TSB treatment, 17 in Nisin and 20 in control) and they did not differ significantly in laying date $\left(\mathrm{X}^{2}=3.85 ; \mathrm{df}=52\right.$; $\mathrm{p}=0.15)$ and clutch size $\left(\mathrm{X}^{2}=2.60 ; \mathrm{df}=52 ; \mathrm{p}=0.27\right)$.

To measure the effects of the treatments on nest bacterial communities, we collected two samples of nest 
material using sterilized tweezers. Samples were taken from a standardized position in the centre of the nest cup at day 9 of incubation, just before spraying the treatment. One sample was placed in a sterile Eppendorf tube filled with $1 \mathrm{ml}$ Phosphate Buffer Saline (PBS) for DNA extraction, the second into PBS with 20\% Glycerol. Glycerol limits crystallization and cellular death when stored at $-20^{\circ} \mathrm{C}$, and therefore allow us to make culturebased analyses. Samples were kept in ice in the field, and stored at $-20^{\circ} \mathrm{C}$ until lab analyses. All sampling and manipulations were made after systematically washing hands and material with 70\% ethanol in order to avoid cross contaminations. All manipulations were performed according to French legislation and permits were obtained from DREAL (Direction Régionale de l'Environnement, de l'Aménagement et du Logement) and CRBPO (Centre de Recherches sur la Biologie des Populations d'Oiseaux; ringing permit $\mathrm{N}^{\circ} 565$ ).

\section{Adult sampling and measurements}

Great tits were trapped in the nest boxes around day 10 post hatching ( 54 females and 44 males), $35.2 \pm 0.6$ days after the beginning of the treatments. We collected twice 10 feathers samples from each individual at a standardized position close to the left leg. As for nest material samples, one sample was placed in PBS, and the other in PBS + Glycerol. We measured tarsus length to the nearest $0.01 \mathrm{~mm}$ using a calliper, body mass with an electronic balance $( \pm 0.01 \mathrm{~g})$ and wing length with a ruler $( \pm 0.1 \mathrm{~mm})$. We found no significant differences in adult tarsus length, wing length and body mass between the treatments (Tarsus length: $\mathrm{F}_{2,51}=1.48 ; \mathrm{P}=0.24$; Wing length: $\mathrm{F}_{2,51}=2.06 ; \mathrm{P}=0.14 ;$ Body mass: $\mathrm{F}_{2,51}=2.74$; $\mathrm{P}=0.08$ ).

We measured the length, width and height of the uropygial gland with a calliper $( \pm 0.01 \mathrm{~mm})$, each one three times, and multiplied the mean values to obtain an index of uropygial gland volume ( $\left.\mathrm{L}^{*} \mathrm{~W} \mathrm{~W}^{*} \mathrm{H}[44]\right)$. Uropygial gland volume was not measured in 2 males, resulting in a sample of 42 males and 54 females in our analyses. In order to avoid any potential observer bias in uropygial gland size measurements, SJ performed all measurements holding the calliper with the scale pointing downward, the values thus visible for the observer only after the measurement. During the second year of the study, we sampled gland secretions by draining the papilla with a glass capillary. We measured the amount of secretions inside the capillary with a calliper $( \pm 0.01 \mathrm{~mm})$ to account for quantity of secretions produced at the moment of sampling, and then placed the capillary in glass vials and stored at $-20^{\circ} \mathrm{C}$ until extraction of organic compounds. Using Great tits included in this experimental study and others captured using mist-nets during autumn of the same year, we found that the volume of the gland is positively correlated with the quantity of secretions drained from the papilla $(\mathrm{F}=41.09 ; \mathrm{df}=109 ; \mathrm{P}<0.001)$. Moreover, the volume of the gland has been suggested to be a better index of production of secretions by the uropygial gland than the quantity of secretions contained inside the papilla at the time of sampling [21]. We used gland volume and not quantity of secretions in our analyses since we made this measurement during the two years of the study. The same observer (SJ) performed all measurements and sampling. Using 20 birds measured twice, we found high repeatability of the mean uropygial gland volume computed as previously described $(\mathrm{r}=0.91 ; \mathrm{df}=20 ; \mathrm{P}<0.001)$.

\section{Uropygial gland composition analyses}

Samples of uropygial gland secretions were diluted in $500 \mu \mathrm{l}$ of hexane, evaporated, and then diluted in $200 \mu \mathrm{l}$ of dichloromethane and vortexed for $1 \mathrm{~min}$ in order to extract organic chemical compounds. Samples were analysed using Gaz Chromatography - Mass Spectrometry (GC-MS; TSQ Quantum; ThermoScientific, plateform MetaToul), with a migration program as follows: $50^{\circ} \mathrm{C}$ for $1 \mathrm{~min}, 10^{\circ} \mathrm{C} / \mathrm{min}$ from $50^{\circ} \mathrm{C}$ to $300^{\circ} \mathrm{C}$ and then $10 \mathrm{~min}$ at $300^{\circ} \mathrm{C}$ (see Additional file 1 for details). Blanks were interspersed between each sample. Resulting profiles were analysed using Xcalibur software to generate composition matrices. Since we cannot standardize the quantity of secretions sampled by the GC-MS, we used matrix of intra-individual relative quantity of compounds in all analyses [45]. Compounds that migrated in unidentifiable complexes or that were at very low quantity were not included in the analyses, leading to 16 chemical compounds retained. These compounds were wax esters, lipids ranging from 33 to 37 carbons. 10 of them being formally identified using trans-esterification by base methanolysis (Table 1; see Additional file 1 for details). GE and AI performed respectively GC-MS and profiles analyses blindly to the treatments, and CD performed compound identification.

\section{Bacterial analyses}

We used respectively culture based and culture independent techniques to measure the density and composition of bacterial communities in the nests and on bird feathers. We sonicated and vortexed bacterial samples to detach microorganisms from nest material and feathers $[21,46]$. To estimate the densities of bacterial communities, we grew them on tryptic soy agar (TSA), a general medium allowing the growth of heterotrophic bacteria. Keratinolytic bacterial densities were estimated with feather meal agar (FMA), a medium containing only keratin as carbon source $[21,46]$. Petri dishes were incubated for 3 days for TSA and 14 days for FMA, at $24^{\circ} \mathrm{C}$ for feather samples and $30^{\circ} \mathrm{C}$ for nest material samples.

We extracted bacterial DNA using Promega extraction protocol (Promega, Fitchburg, WI, USA) from samples 


\begin{tabular}{|c|c|c|c|c|c|}
\hline & Compound & Formula & PC1 & PC2 & PC3 \\
\hline $\bar{A}$ & Pentadecyl octadecanoate & $\mathrm{C} 33 \mathrm{H} 66 \mathrm{O} 2$ & 0.39 & -0.11 & 0.54 \\
\hline B & Hexadecyl 9-octadecenoate & $\mathrm{C} 34 \mathrm{H} 66 \mathrm{O} 2$ & -0.88 & -0.17 & 0.24 \\
\hline$C$ & Hexadecyl octadecanoate & $\mathrm{C} 34 \mathrm{H} 68 \mathrm{O} 2$ & -0.29 & -0.72 & 0.16 \\
\hline $\mathrm{D}$ & Nonadecyl hexadecanoate & $\mathrm{C} 35 \mathrm{H} 70 \mathrm{O} 2$ & 0.55 & -0.14 & 0.56 \\
\hline $\mathrm{E}$ & Unidentified & $\mathrm{C} 35 \mathrm{H} 70 \mathrm{O} 2$ & 0.78 & -0.2 & 0.06 \\
\hline $\mathrm{F}$ & Unidentified & $\mathrm{C} 35 \mathrm{H} 70 \mathrm{O} 2$ & 0.58 & -0.51 & -0.09 \\
\hline G & Heptadecyl 9-octadecenoate & $\mathrm{C} 35 \mathrm{H} 70 \mathrm{O} 2$ & -0.63 & 0.45 & 0.31 \\
\hline $\mathrm{H}$ & Heptadecyl octadecanoate & $\mathrm{C} 35 \mathrm{H} 70 \mathrm{O} 2$ & 0.91 & 0.17 & 0.27 \\
\hline । & Octadecyl 9-octadecenoate & $\mathrm{C} 36 \mathrm{H} 70 \mathrm{O} 2$ & -0.58 & -0.41 & -0.48 \\
\hline J & Octadecyl 9-octadecenoate & $\mathrm{C} 36 \mathrm{H} 70 \mathrm{O} 2$ & -0.85 & 0.07 & 0.24 \\
\hline K & Octadecyl octadecanoate & $\mathrm{C} 36 \mathrm{H} 72 \mathrm{O} 2$ & -0.04 & 0.42 & -0.81 \\
\hline L & Unidentified & $\mathrm{C} 37 \mathrm{H} 74 \mathrm{O} 2$ & 0.87 & 0.2 & 0.16 \\
\hline M & Unidentified & $\mathrm{C} 37 \mathrm{H} 74 \mathrm{O} 2$ & 0.85 & 0.07 & -0.28 \\
\hline$N$ & Unidentified & $\mathrm{C} 37 \mathrm{H} 74 \mathrm{O} 2$ & -0.7 & 0.49 & 0.23 \\
\hline O & Unidentified & $\mathrm{C} 37 \mathrm{H} 74 \mathrm{O} 2$ & 0.8 & 0.03 & -0.22 \\
\hline$P$ & Nonadecyl 9-octadecenoate & $\mathrm{C} 37 \mathrm{H} 72 \mathrm{O} 2$ & -0.34 & -0.79 & -0.1 \\
\hline
\end{tabular}

Factor loadings of the three first principal components summarizing the variance in the chemical composition of uropygial gland secretions in breeding Great tits are shown. The first component represents $45.1 \%$ of the original variance, the second $14.9 \%$ and the third $12.8 \%$ (total $72.8 \%$ ). Each letter indicates a different compound in the GC-MS profiles. Variables included in each principal component are presented in bold.

stored in PBS. We use ARISA (Automated Ribosomal Intergenic Spacer Analysis) to measure bacterial community composition [47]. We amplified highly variable regions of the bacterial ribosomal operon, and measured the length of the amplified fragments by sequencing to obtain profiles composed of several peaks (see Additional file 2 for details), each peak corresponding to an operational taxonomic unit (OTU). This method allows to estimate the diversity of bacterial communities, and to compare samples based on their structure (i.e. the presence or absence of the different OTUs, [47]). The peak profiles obtained for bacterial communities were analysed using $\mathrm{R}$ software with a standardized automatic method [48] in order to obtain the presence/absence data of OTUs. Briefly, this method consists in two steps, the first one aiming at estimating the best shift value and window size to maximize between samples OTUs profile similarity (in this study shift value $=0.1$; window size $=3$ ), the second one allowing to apply these parameters to assemble peaks in OTUs for all samples [48]. We did not detect any contamination of the PBS solution used for sampling since control samples did not contain amplified fragments. Due to technical problems, three samples of nest material were not included in the analyses of bacterial densities (2 from control treatment and 1 from TSB). Moreover, we were unable to extract bacterial DNA from 2 nest samples ( 2 control samples) and 4 feather samples ( 2 from control treatment, 1 from Nisin and 1 from TSB). All lab and peak profile analyses were performed blindly to the treatments by SJ.

\section{Statistical analyses}

All analyses were performed using $\mathrm{R}$ software (version 2.14.0, R Development Core Team 2008). Analyses of differences in bacterial community structure between treatments were performed using non-parametric multivariate analysis of variance based on permutation tests (Adonis; [49]). For the analyses of treatment effects on nest bacterial density, we used linear models with year and date as covariates, whereas linear mixed models (lme, nlme R package) with nest as a random factor were performed to analyse the effects of treatments on feather microbial densities. Finally, we used Shannon diversity index to test for differences in bacterial diversity between the treatments.

We used a principal component analysis (PCA) in order to decompose the variance of chemical composition of secretions into independent components [45]. We estimated individual body condition through the regression of body mass on tarsus length (body mass $=4.19+5.89 \times$ tarsus length; $\mathrm{r}^{2}=0.49 ; \mathrm{T}=5.48 ; \mathrm{p}<0.001 ;$ [50]). We used linear mixed models to analyse the effect of treatments on the volume and composition of the uropygial gland. Date, year, clutch size, body condition and wing length were included as covariates. Year was not included in the analyses of chemical composition since we obtained data only for the second year of the study. Since we expected differences in antimicrobial strategies between sexes, we included a sex by treatment interaction in all models. Treatment nested in the interaction between nest identity and sex was included as a random factor in order to account for the hierarchical structure of our data. Analyses within each sex were performed using linear models (lm, stats R package). Backward selection procedures were applied to remove non-significant factors from the models.

\section{Results}

\section{Bacterial communities in nests and feathers}

From the 52 nest samples analyzed for bacterial community composition, we identified 180 OTUs, whereas feather bacterial communities appeared less diverse with 138 OTUs extracted from the 94 feather samples. Nest communities showed 8 OTUs (4.4\%) with more than $20 \%$ prevalence $(\max 26 \%$ ), and 84 OTUs $(46.7 \%)$ with very low prevalence $(<5 \%)$. Feather communities are composed of 28 OTUs (20.3\%) with more than $20 \%$ prevalence $(\max 67 \%)$, and 44 OTUs $(31.9 \%)$ with very low prevalence $(<5 \%)$. Finally, the number of OTUs detected averaged $45.06 \pm 4.31$ in nest samples and $24.87 \pm$ 2.20 in feather samples. 
We found a significant effect of the treatments on nest total and keratinolytic bacterial densities $(\mathrm{df}=49 ; \mathrm{F}=16.7$; $\mathrm{p}<0.001$ and $\mathrm{df}=49 ; \mathrm{F}=15.7 ; \mathrm{p}<0.001$ respectively; Figure 1). The TSB treatment significantly increased the total and keratinolytic bacterial densities in the nests compared to the control (Table 2). The Nisin treatment significantly decreased both total and keratinolytic bacterial densities in the nests (Table 2). The structure of the bacterial communities in the nests was significantly affected by the treatments (Adonis analysis, Bray-Curtis distance; $\mathrm{df}=49 ; \mathrm{R}^{2}=0.10 ; \mathrm{p}=0.007$ ), with a significant difference between TSB and control treatments (Table 2), whereas Nisin had no significant effect on bacterial community structure compared to the control treatment (Table 2). Using Shannon diversity index, we found a significant effect of the treatments on nest bacterial diversity $(\mathrm{df}=49$; $\mathrm{F}=3.16 ; \mathrm{p}=0.05)$, with TSB treatment increasing nest bacterial diversity (Table 2) whereas Nisin did not affect nest bacterial diversity (Table 2).

The modifications of nest microbiome induced by the treatments (Figure 1) also affected the microbial communities on bird feathers. We found significant differences in total and keratinolytic bacterial loads on feathers between treatments $\quad\left(\mathrm{F}_{2,52}=4.95 ; \mathrm{p}=0.011\right.$ and $\mathrm{F}_{2,53}=13.21$; $\mathrm{p}<0.001$ respectively; Figure 1). TSB increased significantly both total and keratinolytic bacterial loads (Table 2). Interestingly, compared to the control, the Nisin treatment significantly increased feather loads of both total and keratinolytic bacteria (Table 2). The feather bacterial community structure significantly differed between the treatments $\left(d f=53 ; R^{2}=0.11 ; p=0.001\right)$, with TSB treatment significantly affecting bacterial community structure on feathers (Table 2). In contrast, Nisin treatment did not significantly affect feather bacterial community structure (Table 2). Analyses of Shannon diversity index showed no significant effect of the treatments on bacterial diversity (Table 2). Bacterial communities on adults from the two sexes were not differently affected by the treatments (treatment " sex interactions, all $\mathrm{p}>0.05)$. However, females carried higher total and keratinolytic bacterial loads $(0.70 \pm 0.31$ (Estimate $\pm \mathrm{SE}$ ), $\mathrm{df}=33, \mathrm{~T}=2.23, \mathrm{P}=0.033$ and $0.79 \pm 0.26 ; \quad \mathrm{df}=36, \quad \mathrm{~T}=3.03, \quad \mathrm{P}=0.004 \quad$ respectively), showed higher bacterial diversity $(1.02 \pm 0.18, \quad \mathrm{df}=37$; $\mathrm{T}=5.65, \mathrm{P}<0.001)$ and different bacterial community composition $\left(\mathrm{df}=53 ; \mathrm{R}^{2}=0.14 ; \mathrm{P}=0.001\right)$ on feathers compared to males.

\section{Uropygial gland volume and composition}

We found a significant interaction between sex and treatment on the volume of the uropygial gland (Table 3a). Uropygial gland volume significantly differed between treatments in males (Table 4a), being bigger in the TSB $(0.19 \pm 0.07$ (Estimate $\left.\pm \mathrm{SE}) ; \mathrm{F}_{1,28}=8.15 ; \mathrm{p}=0.008\right)$ and Nisin $\left(0.17 \pm 0.07 ; F_{1,25}=5.30 ; p=0.03\right)$ treatments compared to the control (Figure 2b). Females had larger uropygial glands than males $(0.15 \pm 0.04 ; \mathrm{df}=39 ; \mathrm{T}=4.34$; $\mathrm{p}<0.001$ ), but the size of their glands did not differ significantly between treatments (Table 4a, Figure 2a).

Using Shannon diversity index, we found that the mean diversity of chemical compounds contained in gland secretions did not differ significantly between males and females $\left(0.03 \pm 0.04 ; \quad F_{1,21}=0.69 ; \quad p=0.41\right)$. A principal

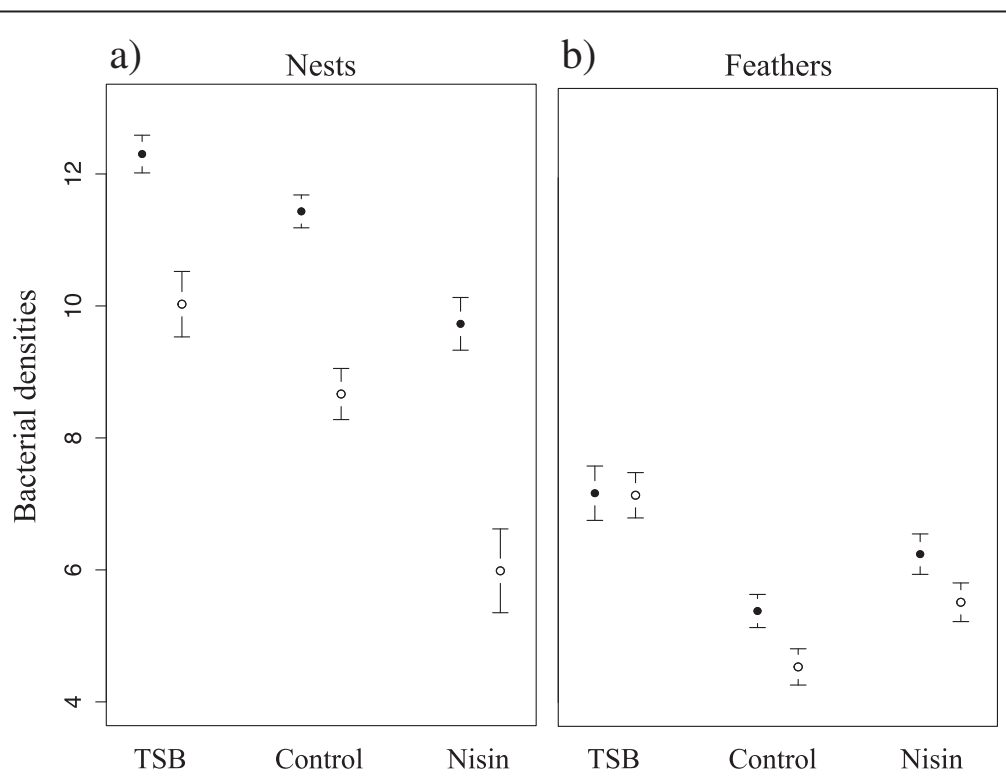

Figure 1 Experimental modification of bacterial densities in nests and on feathers. Full circles represent the total cultivable bacterial densities, empty circles the keratinolytic bacterial densities (a: nests; b: plumage; mean \pm SE of log transformed CFU). Bacterial densities on adults from the two sexes were not differently affected by the treatments (treatment * sex interactions, all P>0.05). 
Table 2 Effects of treatments on density, diversity and composition of nest and feather bacterial communities compared to the control

\begin{tabular}{crrrrrrrr}
\hline & \multicolumn{7}{c}{ Total bacterial densities } & \multicolumn{5}{c}{ Keratinolytic bacterial densities } \\
\hline Nests & Estimate \pm SE & Df & T & P & Estimate \pm SE & Df & T \\
\hline TSB & $0.87 \pm 0.38$ & 32 & 2.30 & $0.028^{*}$ & $1.36 \pm 0.62$ & 32 & 2.19 & $0.036^{*}$ \\
Nisin & $-1.70 \pm 0.46$ & 33 & -3.67 & $<0.001^{* * *}$ & $-2.68 \pm 0.73$ & 33 & -3.65 & $<0.001^{* * *}$ \\
\hline Feathers & Estimate \pm SE & Df & T & P & Estimate \pm SE & Df & T & P \\
\hline TSB & $1.64 \pm 0.61$ & 36 & 2.69 & $0.011^{*}$ & $2.53 \pm 0.52$ & 37 & 4.90 & $<0.001^{* * *}$ \\
Nisin & $0.87 \pm 0.39$ & 34 & 2.20 & $0.035^{*}$ & $0.99 \pm 0.41$ & 35 & 2.43 & $0.021^{*}$ \\
\hline
\end{tabular}

Bacterial diversity

Bacterial composition

\begin{tabular}{crrrrrrrr} 
Nests & Estimate \pm SE & Df & T & P & SumSq & Df & F \\
\hline TSB & $0.60 \pm 0.28$ & 30 & 2.14 & $0.040^{*}$ & 0.80 & 30 & 3.59 & $0.005^{* *}$ \\
Nisin & $-0.01 \pm 0.29$ & 30 & -0.02 & 0.981 & 0.16 & 30 & 0.65 & 0.715 \\
\hline Feathers & Estimate \pm SE & Df & T & $\mathbf{P}$ & SumSq & Df & F & P \\
\hline TSB & $0.41 \pm 0.25$ & 37 & 1.62 & 0.113 & 1.17 & 37 & 7.26 & $0.002^{* *}$ \\
Nisin & $-0.07 \pm 0.32$ & 35 & -0.23 & 0.82 & 0.08 & 35 & 0.51 & 0.767 \\
\hline
\end{tabular}

Significant effects are annotated by ${ }^{*} \mathrm{p}<0.05,{ }^{* *} \mathrm{p}<0.01,{ }^{* *} \mathrm{p}<0.001$.

Table 3 Effects of modification of bird microbiome on uropygial gland volume and composition of secretions

\begin{tabular}{|c|c|c|c|c|c|c|}
\hline \multirow[t]{9}{*}{ a } & \multicolumn{6}{|c|}{ Uropygial gland volume } \\
\hline & & & Estimate $\pm \mathrm{SE}$ & df & $\mathbf{F}$ & $\mathbf{P}$ \\
\hline & \multicolumn{2}{|l|}{ Year } & $0.20 \pm 0.04$ & 1,52 & 29.6 & $<0.001$ \\
\hline & \multicolumn{2}{|l|}{ Wing length } & $0.53 \pm 0.12$ & 1,36 & 19.6 & $<0.001$ \\
\hline & \multirow[t]{2}{*}{ Treatment } & Nisin & $-0.05 \pm 0.06$ & 2,52 & 1.2 & 0.31 \\
\hline & & TSB & $-0.09 \pm 0.06$ & & & \\
\hline & \multicolumn{2}{|l|}{ Sex } & $0.49 \pm 0.08$ & 1,36 & 41.2 & $<0.001$ \\
\hline & \multirow[t]{2}{*}{ Treatment $\times$ Sex } & Nisin & $0.20 \pm 0.09$ & 2,36 & 4.2 & 0.018 \\
\hline & & TSB & $0.24 \pm 0.09$ & & & \\
\hline \multirow[t]{5}{*}{ b } & \multicolumn{6}{|c|}{ Uropygial gland composition - PC1 } \\
\hline & & & Estimate \pm SE & df & $\mathbf{F}$ & $\mathbf{P}$ \\
\hline & \multirow[t]{2}{*}{ Treatment } & Nisin & $0.04 \pm 0.14$ & 2,28 & 3.7 & 0.033 \\
\hline & & TSB & $-0.30 \pm 0.15$ & & & \\
\hline & Sex & & $0.72 \pm 0.12$ & 1,22 & 38.6 & $<0.001$ \\
\hline \multirow[t]{8}{*}{ c } & \multicolumn{6}{|c|}{ Uropygial gland composition - PC2 } \\
\hline & & & Estimate $\pm \mathrm{SE}$ & df & $\mathbf{F}$ & $\mathbf{P}$ \\
\hline & Date & & $0.05 \pm 0.02$ & 1,19 & 5.7 & 0.021 \\
\hline & \multirow[t]{2}{*}{ Treatment } & Nisin & $2.29 \pm 0.58$ & 2,28 & 8.8 & $<0.001$ \\
\hline & & TSB & $1.97 \pm 0.60$ & & & \\
\hline & Sex & & $-2.89 \pm 0.69$ & 1,19 & 17.3 & $<0.001$ \\
\hline & \multirow[t]{2}{*}{ Treatment $\times$ Sex } & Nisin & $2.36 \pm 0.91$ & 2,19 & 5.2 & 0.01 \\
\hline & & TSB & $2.81 \pm 0.92$ & & & \\
\hline
\end{tabular}

d Uropygial gland composition - PC3

\begin{tabular}{rrrrrr} 
& Estimate \pm SE & df & F & & P \\
\cline { 2 - 6 } Sex & $-1.34 \pm 0.35$ & 1,22 & 39.5 & $<0.001$ \\
\hline
\end{tabular}

The compounds produced and their contribution to the principal components are given in Table 1. The table present final models after backward selection. Treatment effects estimates compared to the control are shown. 
Table 4 Analyses of preen gland volume and PC2 composition of secretions for each sex

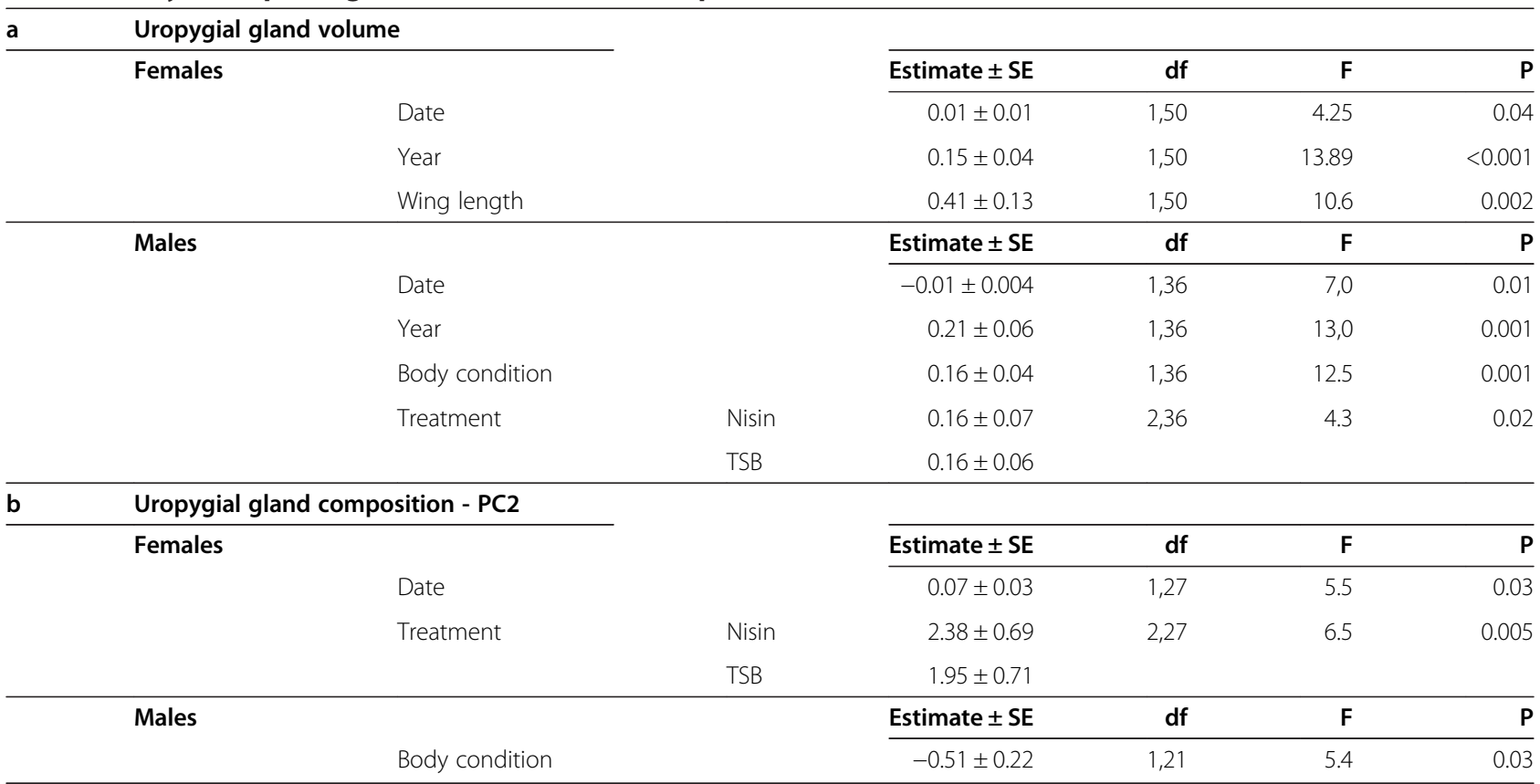

The compounds produced and their contribution to the principal components are given in Table 1. The table present final models after backward selection. Treatment effects estimates compared to the control are shown.

component analysis summarizing the chemical compounds in the gland secretions revealed that a first principal component stands for variation in 12 of the 16 components ( 7 positively and 5 negatively; Table 1 ) and represent $45.1 \%$ of the original variance. The second principal component stands for $14.9 \%$ of the variance and positively correlates with 3 compounds whereas the third represent $12.8 \%$ of the variance and correlates with 3 compounds (Table 1).

We found a significant effect of the treatments on the compounds forming the first principal component (PC1) of uropygial gland secretions (Table 3b; Figure 3a), with an almost significant difference between TSB and control treatments $\left(0.32 \pm 0.15 ; \mathrm{F}_{1,17}=4.33 ; \mathrm{p}=0.053\right)$, but not between Nisin and control $\left(0.04 \pm 0.13 ; F_{1,19}=0.08\right.$; $\mathrm{p}=0.77$ ). The compounds forming the first and third components (PC1 and PC3) of the uropygial gland secretions differed significantly between males and females (Table 3b, d). Moreover, we found a significant interaction between treatment and sex on the scores of the second component (PC2; Table 3c). Separate analyses within each sex revealed a significant effect of the

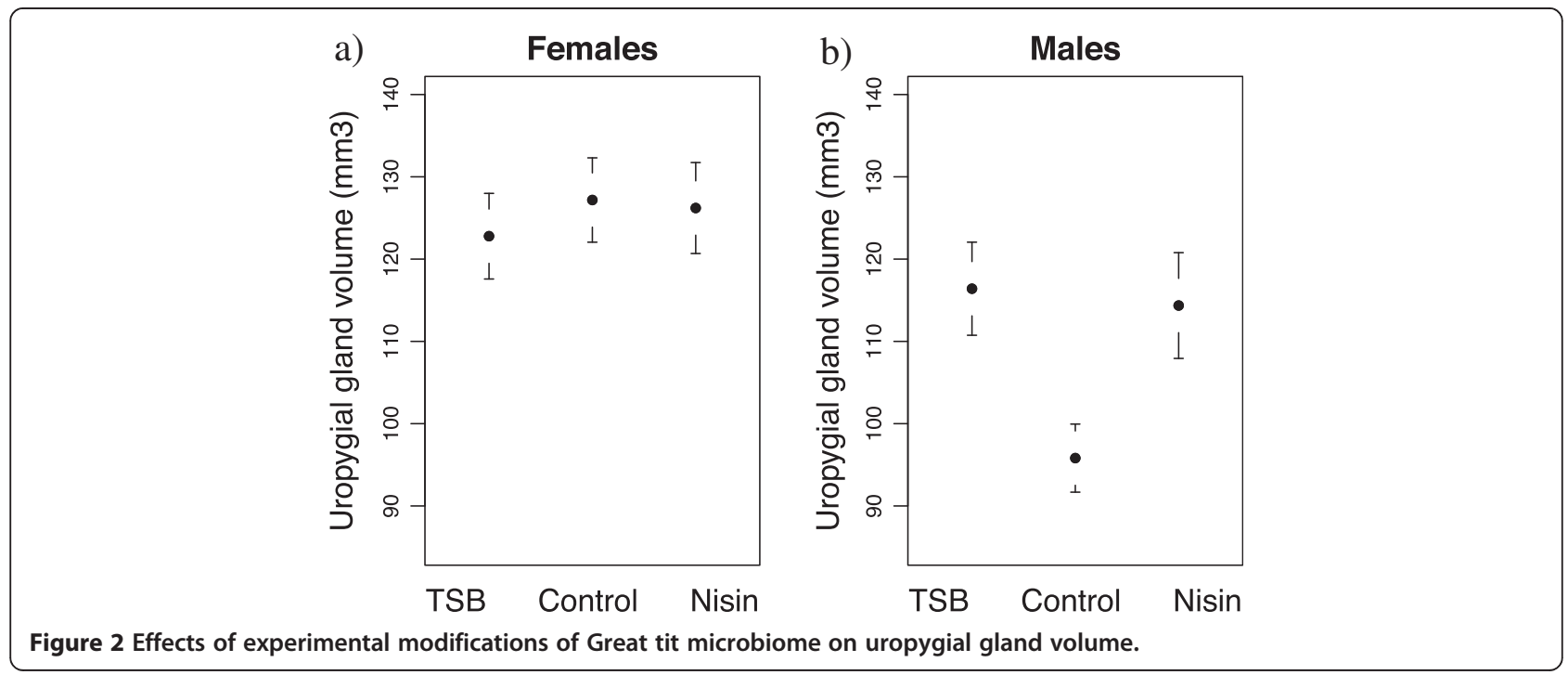




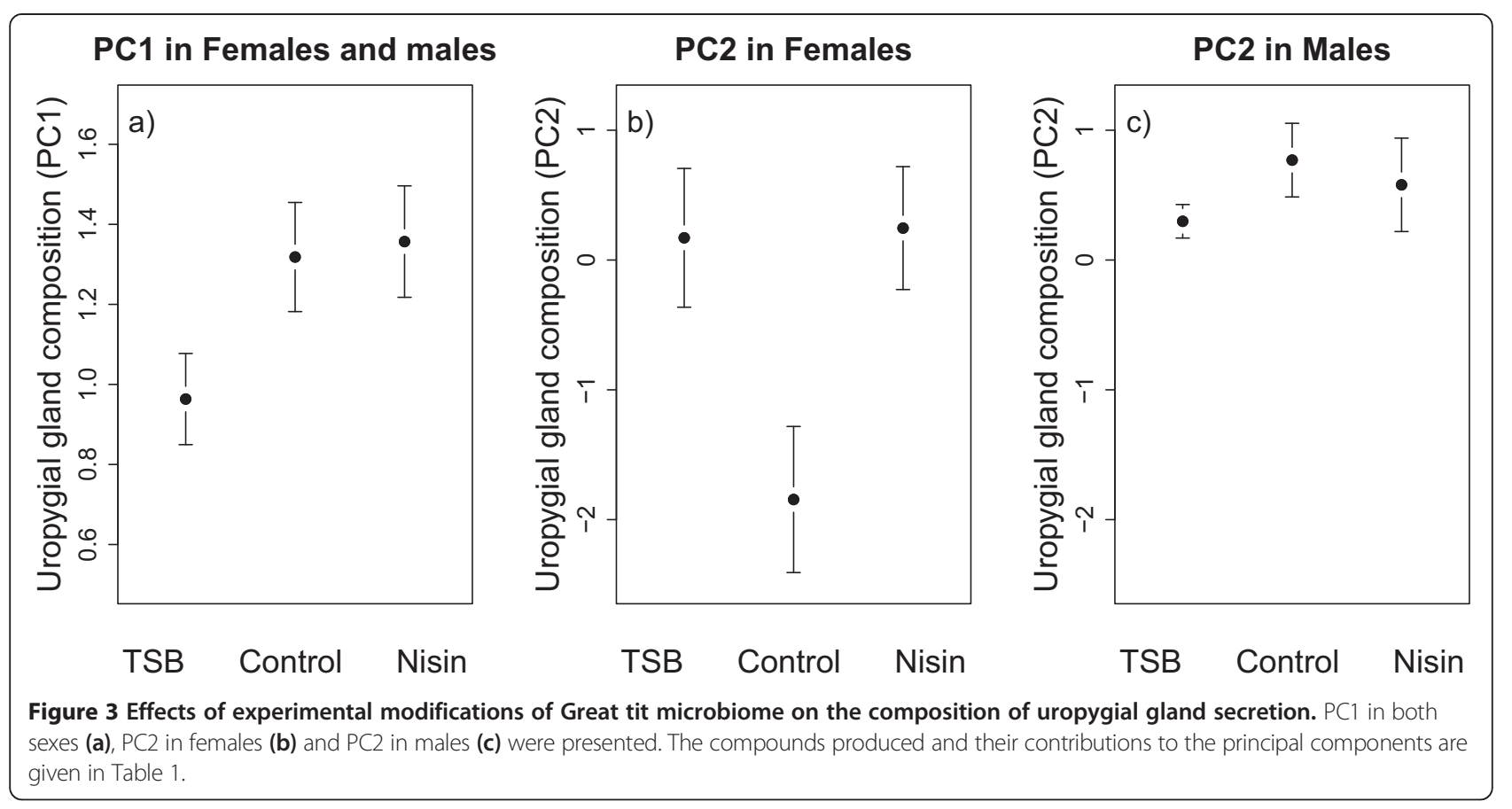

treatments on the second component (PC2) of females but not of males (Table 4b; Figure 3b, c), with females of both TSB and Nisin treatments that significantly differed from control $\left(2.02 \pm 0.78 ; \mathrm{F}_{1,17}=6.74 ; \mathrm{p}=0.019\right.$ and $2.09 \pm 0.73$; $\mathrm{F}_{1,19}=8.16 ; \mathrm{p}=0.010$ respectively). These effects are not related to investment in reproduction since we found no significant effects of clutch size in our analyses (Table 3, 3).

\section{Discussion}

The experimental design we used in this study consisted in favouring or inhibiting microorganisms in the nests of Great tits using a general growth media (TSB) or a large spectrum bacteriostatic (Nisin). Since Great tits are in contact with nest materials during reproduction, we expected these treatments to affect feather bacterial communities. Moreover, since uropygial gland secretions have been found to regulate feather microbial communities [20-24], we expected birds to adjust the volume and composition of this anti-microbial gland depending on their exposure to microorganisms. Accordingly, we found that modifications of Great tit microbiome led to changes in uropygial gland size and composition, providing experimental evidence for microbial induced changes in investment in the uropygial gland.

As expected since Great tits are exposed to nest microorganisms during breeding $[29,51]$, we found that the modifications of nest bacterial communities affected feather communities. We found higher bacterial loads on feathers of females than males. Interestingly, we found no significant interaction between treatment and sex on feather bacterial communities, showing that treatments effects on feather bacteria did not significantly differ between the sexes. This result suggests that although females spend more time than males in the nests for nest building, egg laying, incubation and nestling raising [39], feather bacterial communities of both sexes were equally affected by nest microorganisms.

Interestingly, whereas TSB led to an increase of cultivable bacterial densities both in the nests and on adult feathers, Nisin led to a decrease of bacterial densities in the nests, but not on feathers. Instead, it led to higher loads of both total and keratinolytic bacteria on feathers compared to controls. However, bacterial loads on feathers were lower than densities found in the nests. Competition among microorganisms for space and resources within the microbiome can prevent colonisation by environmental microorganisms $[7,8,18]$. Inhibiting bacterial growth in Great tit nests by the Nisin treatment might have destabilized the feather bacterial community, decreasing the ability of certain microorganisms to outcompete others. Moreover, since birds have been found to regulate their feather bacterial communities by using secretions from their uropygial gland $[20,21]$, the bacterial densities observed on bird feathers might result partly from the ability of birds to shape feather microorganisms using their uropygial gland $[20,21,25,26]$. Disentangling the effects of nest and feather bacterial communities on bird phenotypic traits and investigating the factors that shape feather 
bacterial communities represent promising and important steps for future research in bird-microorganisms interactions.

We found that both sexes modified the production of certain wax esters in gland secretions (summarized in PC1) in response to the TSB treatment. Moreover, we found that only males increased the volume of their uropygial gland in the TSB and Nisin treatments (i.e. when bacterial loads were increased on the plumage) compared to the control. Variation in the quantity of secretions produced by birds has been previously correlated to feather mite and bacterial densities [21,44,52], and secretions have been found to inhibit the growth of five isolated bacteria in vitro [20]. Moreover, Hoopoes (Upupa epops) harbour symbiotic bacteria that produce antimicrobial substances in their uropygial gland, thus protecting them against potential pathogenic microorganisms [19,26,53-55]. In our study, the increase in uropygial gland volume in males exposed to higher bacterial loads on feathers reveal that male Great tits increased their overall investment in the uropygial gland when facing high bacterial exposure.

In contrast to males, females did not significantly modify the volume of their gland according to their microbiome, but modified some wax esters (summarized in PC2) in their secretions when exposed to higher bacterial densities on their feathers. As found in many bird species [45,56-58], the uropygial gland secretions in Great tits are composed of wax esters here ranging from 33 to 37 carbons. Wax esters, as all lipids, are energy stores that can be used by some microorganisms for growth $[59,60]$. Therefore, by preening feathers with wax esters, birds might favour the growth of commensal or mutualistic microorganisms on feathers and as a result limit the colonisation or activity of pathogenic microorganisms through competition between microorganisms $[5,6,19,61]$. However, whether the changes of gland size and composition of secretions led to adaptive regulation of feather bacteria require further experiments. Testing the consequences of changes in quantity and composition of the uropygial gland secretions for regulation of feather bacterial communities is thus an important path for future research about bird-microorganisms interactions.

Three different characteristics of the uropygial gland (i.e. volume, secretion components in PC1 and PC2) varied according to the bacterial modifications in our study. We found that the TSB and Nisin treatments led to modifications of uropygial gland volume in males, and secretion components summarized in PC2 in females. In contrast, the components in $\mathrm{PC} 1$ changed in the two sexes only in response to the TSB treatment. Our results thus showed that the multiple components of the uropygial gland were differentially affected by changes in bird exposure to microorganisms. Some compounds (summarized in PC1) might vary in response to changes in the bird microbiome composition, since only the TSB treatment led to significant changes in nest and feather microbiome composition and also affected compounds in PC1. In contrast, the volume in males and certain secretion components in females (summarized in PC2) might vary according to the bacterial densities on bird feathers, since both treatments led to an increase of the bacterial densities on feathers. In this study, although nest bacterial densities were higher than feather densities, our results suggest that birds did not adjust investment in their uropygial gland according to nest microorganisms, but to those present on their feathers. Our results are in accordance with previous studies suggesting that one main function of the uropygial gland is to regulate feather microorganisms $[20,21,25]$.

Importantly, here we sprayed water in the nests as a control in order to mimic the increase in dampness induced by the TSB and Nisin treatments. Since humidity has been found to affect microbial growth, our control treatment might also have modified the Great tit microbiome, for instance by having favoured bacterial growth in the nests. As a consequence, bacterial densities in our control treatment might be higher than natural bacterial densities in the absence of any manipulation. However, this control treatment was adapted to our experimental design that aimed at testing for differences in Great tit uropygial gland investment between different levels of bacterial exposure. Although additional studies investigating uropygial gland size and composition in relation to natural unaltered microbiome will certainly provide important knowledge about bird-microorganisms interactions, our experimental study showed that Great tits exposed to different levels of bacterial densities modified their investment in their uropygial gland.

The effects of bird microbiome modifications on investment in uropygial gland found here might result from various proximate mechanisms such as skin infections or ingestion of microorganisms [62]. For instance, birds are known to ingest microorganisms present on their feathers during preening [62]. Consequently, the increased bacterial loads on feathers in the TSB and Nisin treatment might result in an increased ingestion of microorganisms, leading to modifications of uropygial gland investment. Recently, it has been found that an increase of testosterone levels stimulates the production of four volatile compounds in captive Dark-eyed juncos (Junco hyemalis) [34]), showing that hormonal regulation can affect the production of chemical compounds contained by the uropygial gland. However, further experiments are required in order to identify the proximate mechanisms responsible for variations in uropygial gland investment in response to microbial exposure.

\section{Conclusions}

Birds live in a bacterial world composed of commensal and pathogenic microorganisms $[1,2,13,17]$. Some of 
these microorganisms can degrade feathers [17], modify predation risks [63], or, after been ingested, affect gut microbial communities and potentially health $[62,64,65]$. The uropygial gland function as a defence mechanism to avoid colonisation and maintenance of pathogenic microorganisms on feathers, and thus protect birds from infections and feather degradation $[20,21,25,26]$. Here we showed, for the first time, that modifications of Great tit microbiome affected investment in the quantity and composition of uropygial gland secretions. Future studies should examine the respective role of quantity and composition of uropygial gland secretions on the regulation of the various pathogenic or beneficial microorganisms inhabiting bird feathers.

\section{Availability of supporting data}

The data sets supporting the results of this article are available in the Dryad repository doi:10.5061/dryad. m8d1c [66] (http://doi.org/doi:10.5061/dryad.m8d1c).

\section{Additional files}

Additional file 1: Overview of the chemical identification of compounds contained in Great tit uropygial gland.

Additional file 2: Details on culture-independent microbial analyses and chemical analyses.

\section{Competing interests}

The authors declare that they have no competing interests.

\section{Authors' contributions}

$\mathrm{SJ}$ and $\mathrm{PH}$ defined the research theme, designed methods and performed the experiment. SJ and NP performed the cultured-based analyses, SJ the cultured-independent analyses, SL, GE and CD the chemical analyses, and SJ and Al analysed the data from chemical analyses. SJ achieved the statistical analyses and wrote the manuscript. All authors contributed to the manuscript writing and approved its final version.

\section{Acknowledgements}

We thank the families Bordes, Gers and Labories who allowed us to install nest-boxes on their site. Carole Sembeille, Marion Roullin, Marc Etchecopart Echechar and Charlotte Perrot helped during the fieldwork. We thank Mélanie Roy, Jean-Baptiste Ferdy and Pascal Le Bourgeois for discussions. The manuscript has greatly benefited from comments by Joselito Acosta and two anonymous referees. This work is part of the 'Laboratoire d'Excellence (LABEX)' entitled TULIP (ANR-10-LABX-41).

\section{Author details}

'Laboratoire Évolution et Diversité Biologique (EDB), UMR 5174 Centre National de la Recherche Scientifique (CNRS), Ecole Nationale de Formation Agronomique (ENFA) - Université Paul Sabatier, 118 Route de Narbonne, 31062 Toulouse, France. ${ }^{2}$ Now at Station d'Ecologie Expérimentale du CNRS à Moulis, USR2936, 09200 Saint-Girons, France. ${ }^{3}$ Laboratoire Ecologie et Evolution, UMR 7625, UPMC CNRS ENS, Université Pierre et Marie Curie, 78 quai St Bernard, 75252 Paris, France.

Received: 14 April 2014 Accepted: 11 June 2014

Published: 17 June 2014

\section{References}

1. McFall-Ngai M, Hadfield MG, Bosch TCG, Carey HV, Domazet-Loso T, Douglas AE, Dubilier N, Eberl G, Fukami T, Gilbert SF, Hentschel U, King N, Kjelleberg S, Knoll AH, Kremer N, Mazmanian SK, Metcalf JL, Nealson K, Pierce NE, Rawls JF, Reid A, Ruby EG, Rumpho M, Sanders JG, Tautz D, Wernegreen JJ: Animals in a bacterial world, a new imperative for the life sciences. Proc Natl Acad Sci U S A 2013, 110:3229-3236.

2. Gilbert S, Sapp J, Tauber A: A symbiotic view of life: we have never been individuals. Q Rev Biol 2012, 87:325-341.

3. Clayton DH, Moore J (Eds): Host-Parasite Evolution: General Principles and Avian Models. Oxford: Oxford University Press; 1997.

4. Stevens CE, Hume ID: Contributions of microbes in vertebrate gastrointestinal tract to production and conservation of nutrients. Physiol Rev 1998, 78:393-427.

5. Davis ME, Brown DC, Baker A, Bos K, Dirain MS, Halbrook E, Johnson ZB, Maxwell C, Rehberger T: Effect of direct-fed microbial and antibiotic supplementation on gastrointestinal microflora, mucin histochemical characterization, and immune populations of weanling pigs. Livest SCi 2007, 108:249-253

6. Kuehl C, Wood H, Marsh T: Colonization of the cecal mucosa by Helicobacter hepaticus impacts the diversity of the indigenous microbiota. Infect Immun 2005, 73:6952-6961.

7. Dillon RJ, Vennard CT, Buckling A, Charnley AK: Diversity of locust gut bacteria protects against pathogen invasion. Ecol Lett 2005, 8:1291-1298.

8. Morgan XC, Segata N, Huttenhower C: Biodiversity and functional genomics in the human microbiome. Trends Genet 2013, 29:51-58.

9. Macpherson AJ, Harris NL: Interactions between commensal intestinal bacteria and the immune system. Nat Rev Immunol 2004, 4:478-485.

10. Ley RE, Lozupone CA, Hamady M, Knight R, Jeffrey I: Worlds within worlds: evolution of the vertebrate gut microbiota. Nat Rev Microbiol 2009 6:776-788

11. Sharon G, Segal D, Ringo JM, Hefetz A, Zilber-Rosenberg I, Rosenberg E: Commensal bacteria play a role in mating preference of Drosophila melanogaster. Proc Natl Acad Sci 2010, 107:20051-20056.

12. Ezenwa VO, Gerardo NM, Inouye DW, Medina M, Xavier JB: Animal behavior and the microbiome. Science (80-) 2012, 338:198-199.

13. Hubalek Z: An annotated checklist of pathogenic microorganisms associated with migratory birds. J Wildl Dis 2004, 40:639-659.

14. Burtt JE, Ichida J: Occurrence of feather-degrading bacilli in the plumage of birds. Auk 1999, 116:364-372.

15. Goldstein G, Flory K, Browne B, Majid S: Bacterial degradation of black and white feathers. Auk 2004, 121:656-659.

16. Shawkey MD, Pillai SR, Hill GE, Siefferman LM, Roberts SR: Bacteria as an agent for change in structural plumage color: correlational and experimental evidence. Am Nat 2007, 169(Suppl(january)):S112-S121.

17. Gunderson AR: Feather-degrading bacteria: a new frontier in avian and host-parasite research? Auk 2008, 125:972-979.

18. Faust K, Sathirapongsasuti JF, Izard J, Segata N, Gevers D, Raes J, Huttenhower C: Microbial co-occurrence relationships in the human microbiome. PLoS Comput Biol 2012, 8:e1002606.

19. Soler JJ, Martín-Vivaldi M, Peralta-Sánchez JM, Ruiz-Rodríguez M, Ruiz M: Antibiotic-producing bacteria as a possible defence of birds against pathogenic microorganisms. Open Ornithol 2010, 2:29-36.

20. Shawkey MD, Pillai SR, Hill GE: Chemical warfare? Effects of uropygial oil on feather-degrading bacteria. J Avian Biol 2003, 34:345-349.

21. Møller AP, Czirjak GÃ, Heeb P: Feather micro-organisms and uropygial antimicrobial defences in a colonial passerine bird. Funct Ecol 2009, 23:1097-1102

22. Moyer BR, Rock AN, Clayton DH: Experimental test of the importance of preen oil in rock doves (Columba livia). Auk 2003, 120:490-496.

23. Vincze O, Vágási CI, Kovács I, Galván I, Pap PL: Sources of variation in uropygial gland size in European birds. Biol J Linn Soc 2013, 110:543-563.

24. Soler JJ, Peralta-Sánchez JM, Martín-Platero a M, Martín-Vivaldi M, MartínezBueno $M$, Møller a P: The evolution of size of the uropygial gland: mutualistic feather mites and uropygial secretion reduce bacterial loads of eggshells and hatching failures of European birds. J Evol Biol 2012, 25:1779-1791. 
25. Czirják GÁ, Pap PL, Vagasi Cl, Giraudeau M, Murean C, Mirleau P, Heeb P: Preen gland removal increases plumage bacterial load but not that of feather-degrading bacteria. Naturwissenschaften 2013, 100:145-151

26. Ruiz-Rodríguez M, Valdivia E, Soler JJ, Martín-Vivaldi M, Martín-Platero a M, Martínez-Bueno M: Symbiotic bacteria living in the hoopoe's uropygial gland prevent feather degradation. J Exp Biol 2009, 212(Pt 22):3621-3626.

27. Lucas F, Moureau B, Jourdie V, Heeb P: Brood size modifications affect plumage bacterial assemblages of European starlings. Mol Ecol 2005, 14:639-646.

28. Lucas FS, Heeb P: Environmental factors shape cloacal bacterial assemblages in great tit Parus major and blue tit $P$. caeruleus nestlings. J Avian Biol 2005, 36:510-516.

29. Kilgas $P$, Saag P, Mägi M, Tilgar V, Mänd R: Plumage bacterial load increases during nest-building in a passerine bird. J Ornithol 2012 153:833-838.

30. Harvell C: The ecology and evolution of inducible defences. Q Rev Biol 1990, 65:323-340

31. Piault R, Gasparini J, Bize P, Paulet M, McGraw KJ, Roulin A: Experimental support for the makeup hypothesis in nestling tawny owls (Strix aluco). Behav Ecol 2008, 19:703-709.

32. Reneerkens J, Piersma T, Damsté JSS: Switch to diester preen waxes may reduce avian nest predation by mammalian predators using olfactory cues. J Exp Biol 2005, 208(Pt 22):4199-4202.

33. Martín-Vivaldi M, Ruiz-Rodríguez M, Soler JJ, Peralta-Sánchez JM, Méndez M, Valdivia E, Martín-Platero AM, Martínez-Bueno M: Seasonal, sexual and developmental differences in hoopoe Upupa epops preen gland morphology and secretions: evidence for a role of bacteria. J Avian Biol 2009, 40:191-205.

34. Whittaker DJ, Soini H a, Gerlach NM, Posto AL, Novotny MV, Ketterson ED: Role of testosterone in stimulating seasonal changes in a potential avian chemosignal. J Chem Ecol 2011, 37:1349-1357.

35. Giraudeau M, Czirják GÁ, Duval C, Bretagnolle V, Gutierrez C, Guillon N, Heeb P: Effect of preen oil on plumage bacteria: an experimental test with the mallard. Behav Processes 2012, 92:1-5.

36. Tschirren B, Fitze PS, Richner H: Sexual dimorphism in susceptibility to parasites and cell-mediated immunity in great tit nestlings. J Anim Ecol 2003, 72:839-845.

37. Gunderson AR, Forsyth MH, Swaddle JP: Evidence that plumage bacteria influence feather coloration and body condition of eastern bluebirds Sialia sialis. J Avian Biol 2009, 40:440-447.

38. Pap PL, Czirják GA, Vágási Cl, Barta Z, Hasselquist D: Sexual dimorphism in immune function changes during the annual cycle in house sparrows. Naturwissenschaften 2010, 97:891-901

39. Gosler A: The Great Tit. Hamlyn Species Guides. London: Paul Hamlyn; 1993.

40. Harris $L$, Fleming $H$, Klaenhammer $T$ : Developments in nisin research. Food Res Int 1992, 25:57-66.

41. Economou T, Pournis N, Ntzimani A, Savvaidis IN: Nisin-EDTA treatments and modified atmosphere packaging to increase fresh chicken meat shelf-life. Food Chem 2009, 114:1470-1476.

42. Wang JM, Firestone MK, Beissinger SR: Microbial and environmental effects on avian egg viability: do tropical mechanisms act in a temperate environment? Ecology 2011, 92:1137-1145.

43. Cook MI, Beissinger SR, Toranzos G a, Arendt WJ: Incubation reduces microbial growth on eggshells and the opportunity for trans-shell infection. Ecol Lett 2005, 8:532-537.

44. Galván I, Sanz JJ: Feather mite abundance increases with uropygial gland size and plumage yellowness in Great Tits Parus major. Ibis (Lond 1859) 2006, 148:687-697.

45. Leclaire S, Merkling T, Raynaud C, Mulard H, Bessière J-M, Lhuillier E, Hatch S a, Danchin E: Semiochemical compounds of preen secretion reflect genetic make-up in a seabird species. Proc Biol Sci 2012, 279:1185-1193.

46. Czirják GA, Møller AP, Mousseau TA, Heeb P: Microorganisms associated with feathers of barn swallows in radioactively contaminated areas around chernobyl. Microb Ecol 2010, 60:373-380.

47. Ranjard L, Brothier E, Nazaret S: Sequencing bands of ribosomal intergenic spacer analysis fingerprints for characterization and microscale distribution of soil bacterium populations responding to mercury spiking. Appl Environ Microbiol 2000, 66:5334-5339.

48. Ramette A: Quantitative community fingerprinting methods for estimating the abundance of operational taxonomic units in natural microbial communities. Appl Environ Microbiol 2009, 75:2495-2505.
49. Anderson MJ: A new method for non-parametric multivariate analysis of variance. Austral Ecol 2001, 26:32-46.

50. Schulte-Hostedde A, Zinner B, Millar J, Hickling G: Restitution of mass-size residuals: validating body condition indices. Ecology 2005, 84:155-163.

51. Saag $P$, Tilgar $V$, Mänd $R$, Kilgas $P$, Mägi M: Plumage bacterial assemblages in a breeding wild passerine: relationships with ecological factors and body condition. Microb Ecol 2011, 61:740-749.

52. Galván I, Barba E, Piculo R, Cantó JL, Cortés V, Monrós JS, Atiénzar F, Proctor $\mathrm{H}$ : Feather mites and birds: an interaction mediated by uropygial gland size? J Evol Biol 2008, 21:133-144

53. Martín-Platero AM, Valdivia E, Ruíz-Rodríguez M, Soler JJ, Martín-Vivaldi M, Maqueda M, Martínez-Bueno M: Characterization of antimicrobial substances produced by Enterococcus faecalis MRR 10-3, isolated from the uropygial gland of the hoopoe (Upupa epops). Appl Environ Microbiol 2006, 72:4245-4249.

54. Martín-Vivaldi M, Peña A, Peralta-Sánchez JM, Sánchez L, Ananou S, Ruiz-Rodríguez M, Soler JJ: Antimicrobial chemicals in hoopoe preen secretions are produced by symbiotic bacteria. Proc R Soc B Biol Sci 2010 277:123-130.

55. Soler JJ, Martín-Vivaldi M, Ruiz-Rodríguez M, Valdivia E, Martín-Platero a M, Martínez-Bueno M, Peralta-Sánchez JM, Méndez M: Symbiotic association between hoopoes and antibiotic-producing bacteria that live in their uropygial gland. Funct Ecol 2008, 22:864-871.

56. Whittaker DJ, Soini H a, Atwell JW, Hollars C, Novotny MV, Ketterson ED: Songbird chemosignals: volatile compounds in preen gland secretions vary among individuals, sexes, and populations. Behav Ecol 2010, 21:608-614.

57. Reneerkens J, Piersma T, Sinninghe Damsté JS: Sandpipers (Scolopacidae) switch from monoester to diester preen waxes during courtship and incubation, but why? Proc Bio/ Sci 2002, 269:2135-2139.

58. Leclaire S, Merkling T, Raynaud C, Giacinti G, Bessière J-M, Hatch S a, Danchin E: An individual and a sex odor signature in kittiwakes?: study of the semiochemical composition of preen secretion and preen down feathers. Naturwissenschaften 2011, 98:615-624.

59. Shelley W, Hurly HJ, Nichols AC: Axillary odor: experimental study of the role of bacteria, apocrine sweat, and deodorants. Arch Dermatol 1953, 68:430.

60. Ara K, Hama M, Akiba S, Koike K, Okisaka K, Hagura T, Kamiya T, Tomita F: Foot odor due to microbial metabolism and its control. Can J Microbiol 2006, 52:357-364

61. Currie C, Scott J, Summerbell R, Malloch D: Fungus-growing ants use antibiotic-producing bacteria to control garden parasites. Nature 1999, 398:701-704.

62. Kulkarni S, Heeb P: Social and sexual behaviours aid transmission of bacteria in birds. Behav Processes 2007, 74:88-92.

63. Møller AP, Erritzøe J, Tøttrup Nielsen J: Predators and microorganisms of prey: goshawks prefer prey with small uropygial glands. Funct Ecol 2010, 24:608-613.

64. Kohl KD: Diversity and function of the avian gut microbiota. J Comp Physiol 2012, 182:591-602.

65. Potti J, Moreno J, Yorio P, Briones V, Garcia-Borboroglu P, Villar S, Ballesteros $C$ : Bacteria divert resources from growth for magellanic penguin chicks. Ecol Lett 2002, 5:709-714.

66. Jacob S, Immer A, Leclaire S, Parthuisot N, Ducamp C, Espinasse G, Heeb P. Data from: Uropygial gland size and composition varies according to experimentally modified microbiome in Great tits. Dryad. doi:10.5061/ dryad.m8d1c.

doi:10.1186/1471-2148-14-134

Cite this article as: Jacob et al:: Uropygial gland size and composition varies according to experimentally modified microbiome in Great tits. BMC Evolutionary Biology 2014 14:134 